\title{
GENETIC VARIATION OF YELLOW BARBELL (CARASOBARBUS LUTEUS (HECKEL, 1843)) FROM FOUR POPULATIONS USING MITOCHONDRIAL DNA COI GENE SEQUENCES
}

\author{
PARMAKSIZ, A.*-ESKICI, H. K. \\ Harran University, Faculty of Science-Literature, Department of Biology, Şanliurfa, Turkey \\ (phone: +90-414-318-3562; fax: +90-414-318-3541) \\ *Corresponding author \\ e-mail:aprmksz@gmail.com \\ (Received $22^{\text {nd }}$ Nov 2017; accepted $27^{\text {th }}$ Feb 2018)
}

\begin{abstract}
The aim of this study is to determine genetic variation of $C$. luteus populations by conducting gene sequence analysis of mtDNA COI locus. Total DNA of 48 individuals from 4 populations in total was isolated using a commercial kit. Sequence analysis was conducted through 3500 XL Genetic Analyzer device following the amplification of target mtDNA locus via Polymerase Chain Reaction (PCR). With sequence analysis of mtDNA COI locus, 9 polymorphic sites and 4 haplotypes were determined. Haplotype and nucleotide diversity were calculated between $0.409-0.535$ and $0.00089-0.00534$, respectively. Pairwise $\mathrm{F}_{\mathrm{ST}}$ results ranged between -0.16880 and 0.33181 , values of Diyarbakır population were found to be statistically significant compared to all of the other populations. Totally 4 haplotypes were detected in Median-Joining Network haplotype network. Tajima's D and Fu' Fs tests values were statistically insignificant for all populations ( $>0.05$ ). All results obtained in this study are the data that were extracted for $C$. luteus species for the first time. Haplotypes determined for mtDNA COI 625 locus are new results for the literature, generated a critical data set in terms of genetic diversity of this species.
\end{abstract}

Keywords: population genetic, haplotype, polymorphism, Euphrates River, Tigris River

\section{Introduction}

Carasobarbus luteus (Heckel, 1843) is an endemic species from the family Cyprinidae possessing a wide distribution in Euphrates and Tigris River, natural and artificial lakes across Mesopotamia (Kuru, 1979; Ünlü, 1991; Gökçek and Akyurt, 2008; Coad, 2010). The body is covered with large, rounded scales. The length and weight varies between $9-35 \mathrm{~cm}$, 20-350 grams, respectively. The color is brownish yellow on the back and yellowish or yellowish white on the sides. The mouth is terminal or semi-terminal and has a pair of short mustaches. Since the meat is delicious, it is used as food by local people (Bilici, 2013). This species is also of economic importance due to high demand as food (Borkenhagen et al., 2011; Bilici et al., 2016).

Certain studies such as reproductive biology (Ahmed et al., 1984, Bilici et al., 2016), feeding condition (Naama and Muhsen, 1986), gonad development (Bartel et al., 1996), observations of reproductive organs and tissues (Rahemo and Al-Shatter, 2012), some biological characteristics (Al-Hazzaa, 2005; Asmaa et al., 2013; Baboli et al., 2013; Eydizadeh, 2014), spermatologic characteristics (Aral et al., 2014), characteristics of age and growth (Gökçek and Akyurt, 2008), content of digestive system (Çelik and Saler, 2016) were conducted on this species.

The genetic variation and population structure of the commercially important species should be studied for the management and conservation purposes (Ward, 2000; Ortega et al., 2006). However, there has not been any study about genetic variation of the species $C$. luteus thriving in rivers systems of Euphrates and Tigris. 
In recent years, developments in sequencing techniques have made mtDNA studies popular (Liu and Zhou, 2016). If compared to nuclear markers, mtDNA markers are more sensitive to the effects of genetic drift (Filipova et al., 2011).

Because of maternal inheritance and fast evolutionary rate, it has become an important tool of comparative genomics and plays an important role in molecular diversity study and population genetic structure (Near et al., 2003; Cardenas et al., 2009; Xu et al., 2011).

$\mathrm{COI}$ is a protein-coding gene in mtDNA owing to fast evolution, easy amplification and sequencing, it has shown precious knowledge and largely used as genetic marker for population genetic studies (Near et al., 2003; Hu et al., 2008; Cardenas et al., 2009; Xu et al., 2011).

The aim of this study is to determine the genetic variations in populations of $C$. luteus, naturally thriving in Euphrates and Tigris Rivers, by conducting sequence analysis for mtDNA COI locus.

\section{Materials and Methods}

\section{Study area, Sample collection and DNA extraction}

Euphrates-Tigris river system, large river system of southwestern Asia and it comprises the Euphrates and Tigris rivers, which follow approximately parallel courses by way of the heart of the Middle East (Britannica, 2018). The two rivers have their resources in 50 miles of each other in eastern Turkey and tour southeast through northern Syria and Iraq to the head of the Persian Gulf (Britannica, 2018). Besides, Euphrates and Tigris river systems have a great deal of important capacity and potential for fish biodiversity and fishery. The localities of Euphrates River (Adiyaman and Hilvan) and Tigris River (Diyarbakır and Bismil) System were found to be appropriate for sampling because of the number of populations, the availability of land conditions, the availability of sufficient number of fishermen and the proximity to the city center.

Fish samples, including 48 individuals from 4 populations in total, 2 populations in Euphrates River (Adiyaman and Hilvan) and 2 populations in Tigris River (Diyarbakır and Bismil), were caught by fishing (Figure 1) between January 2013 and December 2013. Number of localities and samples were given in Table 2.

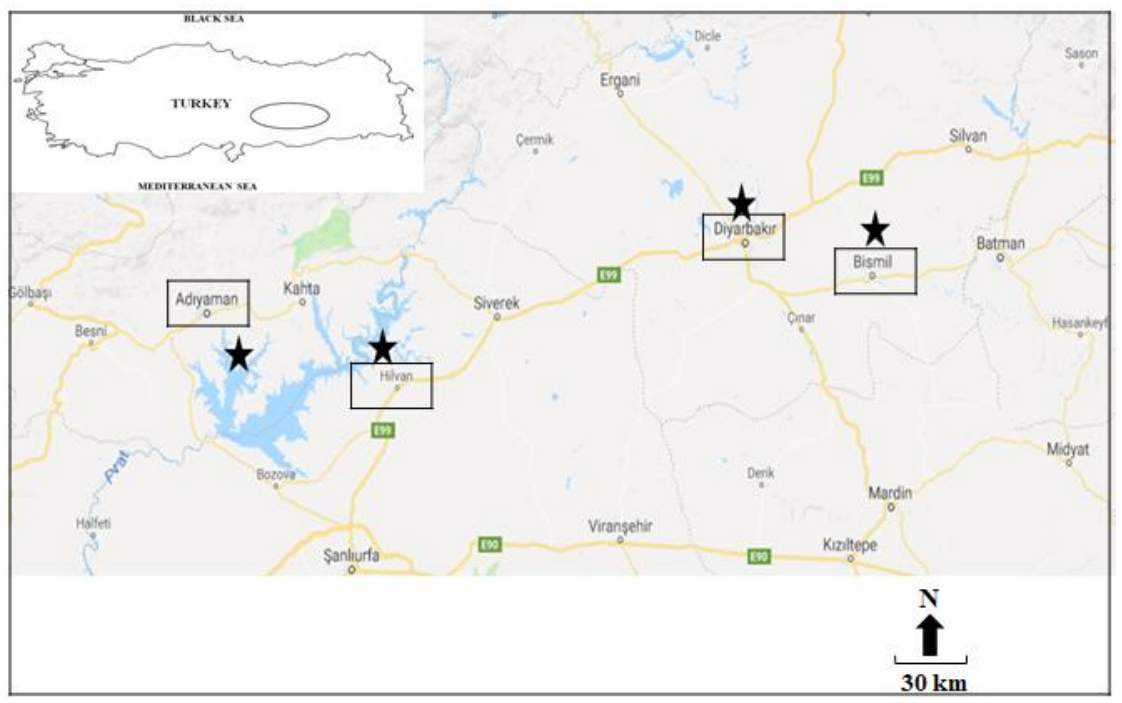

Figure 1. Location of study area 
$1 \mathrm{~g}$ specimen was dissected from muscle tissue on the base of pectoral fin of fish samples, conserved in micro centrifuge tubes with $1,5 \mathrm{ml}$ volume containing $95 \%$ ethanol at $+4{ }^{\circ} \mathrm{C}$ until DNA isolation. Total DNA isolation was performed using GeneJET Genomic DNA Purification Kit (ThermoScientific). $2 \mu 1$ of isolated DNA samples was taken to run in $0.8 \%$ agarose gel at 120 Volts for 30 minutes, then viewed.

\section{PCR amplification and sequencing}

Primers used for amplification of mtDNA COI locus in the study by Darabi (2014) COI-625F (5'-TCA-ACC-AAC-CAC-AAA-GAC-ATT-GGC-AC-3') and COI-625R (5'-GAC-TTC-TGG-GTG-GCC-AAA-GAA-TCA-3') were used in the present study.

All PCR reactions were performed at a total volume of $25 \mu 1$ containing $0.5 \mathrm{mM}$ of each primer, $0.2 \mathrm{mM}$ of each dNTP, 1x PCR buffer, $2.5 \mathrm{mM} \mathrm{MgCl}_{2}, 1$ unit Taq polymerase and approximately $90 \mathrm{ng}$ of template DNA. The PCR amplification was carried out in a BIO-RAD T100 ${ }^{\mathrm{TM}}$ Thermal Cycler under the following conditions: 3 min initial denaturation at $95^{\circ} \mathrm{C}$, and 35 cycles of $30 \mathrm{~s}$ at $95^{\circ} \mathrm{C}$ for denaturation, $30 \mathrm{~s}$ at $62^{\circ} \mathrm{C}$ for annealing, and $45 \mathrm{~s}$ at $72{ }^{\circ} \mathrm{C}$ for extension, and a final extension at $72{ }^{\circ} \mathrm{C}$ for $10 \mathrm{~min}$. A total of $3 \mu \mathrm{l}$ of each PCR product was checked on $2 \%$ agarose gel electrophoresis with a Ladder (GeneRuler ${ }^{\mathrm{TM}} 100$ bp DNA Ladder, ready-to-use, Fermentas) and the most specific products were selected for sequencing. Amplified PCR products were purified using the Favor/Prep gel/PCR purification mini kit (Favorgen, Vienna, Austria). Sequencing was done with an automated DNA sequencer 3500 XL Genetic Analyser (Thermo Fisher Scientific).

\section{Sequence analysis}

The raw data of mtDNA COI sequences obtained from commercial company were evaluated and converted into FASTA format by ChromasPro v 2.0.1 software (http://www.technelysium.com.au/ChromasPro.html). Resulting sequences of all individuals in FASTA format were aligned using BioEdit software version 7.2.5 program (Hall, 2013). The number of polymorphic sites and haplotypes, diversity of haplotypes and nucleotides, Tajima D and Fu's Fs statistics were calculated for populations using DnaSP version 5.10.01 program (Rozas et al., 2003). The phylogenetic relationship between haplotypes was identified by Network version 4.6 software (http://www.fluxus-engineering.com, Rohl, 1999).

\section{Results}

\section{Genetic variation}

An average of $620 \mathrm{bp}$ fragments of mtDNA COI 625 locus from 48 C. luteus specimens were sequenced; totally 9 variable sites and 4 haplotypes were detected. Nucleotide variations of this region are shown in Table 1.

As seen in Table 2, $\mathrm{H} 1$ is the haplotype which is commonly seen in all of the populations. Haplotype $\mathrm{H} 2$ is found in all of the populations except Diyarbakir. Haplotype H3, on the other hand, is observed only in Bismil population, $\mathrm{H} 4$ only in populations of Tigris River. Bismil population alone includes all of the 4 haplotypes. Nucleotide composition of this site which is approximately $620 \mathrm{bp}$ is cytosine (C), thymine (T), adenine (A) and guanine (G), 26.94\%, 29.35\%, 26.94\%, and $77 \%$ respectively. Haplotype and nucleotide diversity were calculated in a range of 0.409 - 
0.535 and $0.00089-0.00534$, respectively. Hilvan population was the one with the lowest results for haplotype diversity and values determined for other populations were similar. Adiyaman population was determined to have the highest nucleotide variation, Diyarbakır population had the lowest.

Table 1. Haplotypes and nucleotide variations of mtDNA COI 625

\begin{tabular}{cccccccccc}
\hline Haplotypes & $\mathbf{2 3 6}$ & $\mathbf{2 5 7}$ & $\mathbf{2 6 3}$ & $\mathbf{2 7 5}$ & $\mathbf{3 4 4}$ & $\mathbf{3 6 2}$ & $\mathbf{4 9 1}$ & $\mathbf{5 0 4}$ & $\mathbf{5 8 7}$ \\
\hline H1 & T & T & C & C & G & C & G & T & G \\
H2 & C & C & T & T &. & T &. & C &. \\
H3 &. &. &. &. & A &. & A &. & . \\
H4 & . & . &. &. &. &. &. &. & A \\
\hline
\end{tabular}

Table 2. C. luteus sample site, size and their genetic diversity inferred from mtDNA COI gene sequence ( $n=$ number of individuals, Nh: number of haplotypes, Hd: haplotype diversity, $\pi$ : nucleotide diversity)

\begin{tabular}{|c|c|c|c|c|c|c|c|c|}
\hline $\begin{array}{c}\text { River } \\
\text { System }\end{array}$ & Locality & $\mathbf{n}$ & Nh & $\begin{array}{l}\text { Haplotype } \\
\text { frequency }\end{array}$ & Hd & $\pi$ & $\begin{array}{c}\text { Tajima's } \\
\text { D }\end{array}$ & Fu's Fs \\
\hline $\begin{array}{c}\text { Euphrates } \\
\text { River }\end{array}$ & Adiyaman & 6 & 2 & $\begin{array}{l}\text { H1 (0.66) } \\
\text { H2 (0.34) }\end{array}$ & 0.533 & 0.00534 & 1.24649 & 4.184 \\
\hline $\begin{array}{c}\text { Euphrates } \\
\text { River }\end{array}$ & Hilvan & 12 & 2 & $\begin{array}{l}\text { H1 }(0.75) \\
\text { H2 }(0.25)\end{array}$ & 0.409 & 0.00410 & 0.89777 & 5.083 \\
\hline Tigris River & Bismil & 22 & 4 & 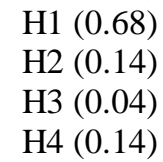 & 0.519 & 0.00319 & -0.75999 & 1.799 \\
\hline Tigris River & Diyarbakır & 8 & 2 & $\begin{array}{l}\text { H1 (0.37) } \\
\text { H4 (0.63) }\end{array}$ & 0.535 & 0.00089 & 1.16650 & 0.866 \\
\hline
\end{tabular}

\section{Population genetic structure}

As seen in Table 3, Pairwise $\mathrm{F}_{\mathrm{ST}}$ values range between -0.16880 and 0. 33181. Despite values between populations of Adiyaman, Hilvan and Bismil were statistically insignificant, values of Diyarbakır population yielded as statistically significant compared to all of the other populations.

Table 3. Pairwise $F_{S T}$ values (below diagonal) and $p$ values (above diagonal) between four populations of $C$. luteus

\begin{tabular}{ccccc}
\hline Locality & Adiyaman & Hilvan & Bismil & Diyarbakir \\
\hline Adiyaman & 0.00000 & $0.99967 \pm 0.0000$ & $0.45818 \pm 0.0089$ & $0.01421 \pm 0.0023$ \\
Hilvan & -0.12296 & 0.00000 & $0.49686 \pm 0.0092$ & $0.04992 \pm 0.0034$ \\
Bismil & 0.01223 & -0.16880 & 0.00000 & $0.04661 \pm 0.0034$ \\
Diyarbakir & $0.33181^{*}$ & $0.25595^{*}$ & $0.12370^{*}$ & 0.00000 \\
\hline
\end{tabular}

$* \mathrm{p}<0.05$ 
The analysis of molecular variance of population structure revealed that percentage of variation between groups was $7.37 \%$, among populations within groups $1.28 \%$ and within population $91.35 \%$. Fixation index was calculated as 0.08646 (Table 4).

Table 4. Analysis of molecular variance (AMOVA) of four populations of C. luteus based on mtDNA COI gene sequences

\begin{tabular}{lllllll}
\hline \multicolumn{1}{c}{ Source of variation } & d $f$ & $\begin{array}{c}\text { Sum of } \\
\text { squares }\end{array}$ & $\begin{array}{c}\text { Variance } \\
\text { components }\end{array}$ & $\begin{array}{c}\text { Percentage } \\
\text { of } \\
\text { variation }\end{array}$ & $\begin{array}{c}\text { Fixation } \\
\text { Indices }\end{array}$ & p-value \\
\hline $\begin{array}{l}\text { Among groups } \\
\text { Among populations within } \\
\text { groups }\end{array}$ & 1 & 2.958 & $0.07958 \mathrm{Va}$ & 7.37 & & \\
Within populations & 2.246 & $0.01381 \mathrm{Vb}$ & 1.28 & & \\
Total & 44 & 43.420 & $0.98683 \mathrm{Vc}$ & 91.35 & $\mathbf{F}_{\text {ST: }}$. & \\
\hline
\end{tabular}

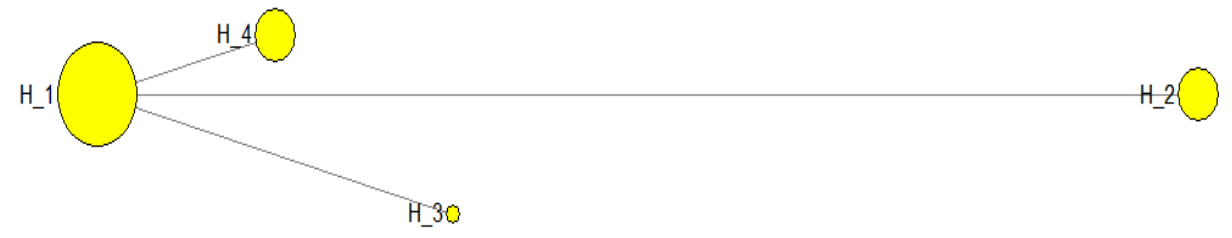

Figure 2. Median-joining network showing relations among 4 haplotypes of four C. luteus population

In Median-Joining Network haplotype network created for 48 C. luteus samples analyzed, totally 4 haplotypes were determined, resulting network shows presence of a central haplotype (H1) which indicates an evolutionary connection. In addition, it is possible to speculate that all of the other haplotypes are connected with haplotype $\mathrm{H} 1$ (Figure 2).

\section{Neutrality tests}

Neutrality tests (Tajima's D and Fu' Fs tests) were applied for each population. It was determined that while Tajima's D values were negative for Bismil population, they were positive for other population, were statistically insignificant for all of the populations $(p>0.05)$. Fu' Fs tests values were calculated to be positive and were statistically insignificant for all of the populations ( $p>0.05)($ Table 2).

\section{Discussion}

In this study, genetic variation of populations was researched via sequence analysis of mtDNA COI 625 locus in 48 C. luteus samples from totally 4 populations in Euphrates and Tigris Rivers. 9 polymorphic sites and 4 haplotypes were determined for this studied locus. H1 was the most frequently observed haplotype for 31 individuals in total, it is possible to say that $\mathrm{H} 1$ is ancestry because it is common for all of the populations. In addition, haplotype $\mathrm{H} 2$ is also represented in other 3 populations except Diyarbakır population. Haplotype $\mathrm{H} 3$ was seen in only 1 individual from Bismil 
population. Haplotype $\mathrm{H} 4$ was represented by 3 individuals from Bismil, 5 individuals from Diyarbakır as well. Haplotypes H3 and H4 are unique to Tigris River. Haplotype diversity between studied populations was calculated to be considerably similar except Hilvan population. Even though it has the highest haplotype diversity (0.535), Diyarbakir population has the lowest nucleotide variation (0.00089). Mean haplotype diversity and nucleotide diversity were determined to be 0.538 and 0.00345 , respectively.

In a study by Parmaksız and Ekşi (2017) which was conducted on populations of Capoetta trutta in habiting in the same systems, using the same primers, haplotype diversity was determined as 0.642 , nucleotide diversity as 0.00138 . Despite the fact that haplotype variation was lower in this study, nucleotide variation was found to be higher.

Environmental heterogeneity and large population sizes might support the maintenance of high haplotype diversity within populations (Nei, 1987; Avise, 1998). The nucleotide diversity $(\pi)$ value indicates the mean number of differences among all pairs of haplotypes in each population (Saraswat et al., 2014). So, $\pi$ values are a susceptible index of the genetic diversity for a population (Nei and $\mathrm{Li}, 1979$ ). Low nucleotide diversity and high haplotype diversity in fish presumably underwent population expansion after a period of low-effective population size (Saraswat et al., 2014). Low nucleotide diversity values are also indicative of low population diversity and genetic diversity is effected by many factors, such as habitation, bottleneck effects and anthropogenic activity (Ma et al., 2010, Fennando et al., 2000). Because the four localities where samples of our study were taken from were close to residential areas, this fish species is caught by fishermen and local people. These caught fish are both consumed by local people and sold to neighboring provinces. As the rate of fishing is high, genetic diversity of $C$. luteus populations has been decreasing.

In Median Joining network analysis, haplotype H1 is in the center of the network and dominant, all other haplotypes were consisted of haplotype H1 (Figure 2). The fact that this haplotype is found all of the haplotypes and dominant indicates that this one is ancestral haplotype.

Inter-population pair wise $\mathrm{F}_{\mathrm{ST}}$ values varied between -0.16880 and 0.33181 (Table 3). Though differences between Bismil populations were insignificant, differences between Diyarbakır and all of the other populations were determined to be statistically significant.

In this study, AMOVA analysis conducted based upon the haplotype frequencies indicated that percentage of variation between groups was $7.37 \%$, among population within groups $1.28 \%$ and within population $91.35 \%$ (Table 4). The mean fixation index was calculated as 0.08646 .

In their study, Parmaksız and Ekşi (2017) calculated within population and among population within groups genetic variation as $90.14 \%$ and $9.86 \%$, respectively; mean fixation index as 0.09865 . The current study is compatible with results of this study. Low inter-population genetic variance is an indicator for that there has been a high gene flow between these populations or these populations were the ones isolated from each other last. Tigris River rises in Turkey and flows in to Persian Gulf in Shatt al-Arab passing through lands of Iraq (Zeybek et al., 2016). It can be said that there was a gene exchange between populations of this fish species because of the union before dams had been constructed on these river systems.

Tajima's D values in the populations; were positive for populations of Adiyaman, Hilvan, Diyarbakır, negative for Bismil population and all of the resulting values did not 
yield statistically significant ( $>0.05$ ). Fu's Fs values, on the other hand, were positive for all of the populations and were not statistically significant as well ( $p>0.05)$. Mean Tajima's D value was determined to be 0.05729 and Fu's Fs value was 3.351.

Parmaksız and Ekşi (2017), in their study, calculated mean Tajima's D and Fu's Fs values as -1.08945 and -2.946 , respectively and both of the values were they were negative while they were positive in the current study.

Tajima's D is used to measure the distinctness between the number of segregating sites and the pair wise genetic distance ( $\mathrm{Li}$ et al., 2015). A positive Tajima's D and Fu's Fs Test signifies low levels of both low and high frequency polymorphisms, indicating a decrease in population size (Hu et al., 2016).

When neutrality tests in this study were considered, while there was a decrease in populations of Adiyaman, Hilvan and Diyarbakir population, a decrease was not observed for Bismil population. In addition, the fact that all 4 haplotypes were seen in Bismil population indicates that the populations has not decreased. The reason why the number of haplotypes in Bismil locality is high might be due to the presence of a large number of streams. Furthermore, the H3 haplotype is still present in the population of Bismil, but it might end up in other localities.

All of the results obtained via this study are the data of $C$. luteus obtained for the first time. Haplotypes determined for mtDNA COI 625 locus were new results for literature, created a significant data set in terms of genetic variation of this species (Table 5).

Table 5. Total haplotypes of C. luteus in the present study and Gen Bank

\begin{tabular}{|l|l|}
\hline Haplotype & Gen Bank Data \\
\hline H1 & The current study \\
\hline H2 & The current study \\
\hline H3 & The current study \\
\hline H4 & The current study \\
\hline H5 & KM590426.1 \\
\hline H6 & KM590425.1 \\
\hline H7 & KM590424.1 \\
\hline
\end{tabular}

\section{Conclusions}

Carasobarbus luteus (Heckel, 1843) has a wide distribution and the most common species in both Euphrates and Tigris basins (Kuru, 1979; Ünlü, 1991; Coad, 2010). This species is endemic and the most economically important and abundant species in the region (Bilici et al., 2017). The population of this species have been influenced by pollution, destruction of habitat and especially over fishing exploitation.

In this study, the sampling localities were only four localities. Moreover, the outcome based on COI gene presented only a portion of the entire genome here that could be only a partial solution for population genetic of the species (Gruenthal et al. 2007). Further study based on nuclear markers, mtDNA markers (cyt-b, D-loop) and a wide range sampling collection is needed to extend and corroborate the present population genetic structure.

Acknowledgements. This study was funded by Harran University Research Fund (Project No:16040). 


\section{REFERENCES}

[1] Ahmed, H. A., Al-Mukhtar, M. A., Al-Adhub, H. Y. (1984): The reproductive biology of Carasobarbus luteus (Pisces Cyprinidae) in Al-Hammar Marsh, Iraq. - Cybium 18 (4): 69-80.

[2] Al-Hazzaa, R. (2005): Some biological aspects of the himri barbel, Barbus luteus in the intermediate reaches of the Euphrates River. - Turk. J. Zool. 29(4): 311-315.

[3] Aral, F., Doğu, Z., Şahinöz, E. (2014): Comparion of spermatological characteristics in Carasobarbus luteus (Heckel, 1843) and Carassius carassius living in Atatürk Dam Lake. - Turk. J. Agric. Food Sci. Technol. 2 (4): 185-189.

[4] Asmaa, S. I., Taha, Y. A., Nada, A. A. (2013): Study of sexual dimorphism in Iraqi fresh water fish B. luteus. - J. of Genet. and Envir. Res. Cons. 1(1): 12-19.

[5] Avise, J. (1998): Phylogeography. - Cambridge, MA. Harvard University Press., 102 pp.

[6] Baboli, M., Nejad, M. (2013): Condition factor, diet and gonado somatik index of C.luteus (Heckel, 1843) in Karkheh River, Iran. - J. Bio. \&Env. Sci. 3(1): 83-87.

[7] Bartel, R., Bieniarz, K., Epler, P., Kime, D. E., Popek, W., Sokolowska-Mikolajczyk, M. (1996): Gonadal development and spawning of Barbus sharpei, Barbus luteus and Mugil fish in fresh and saltwater lakes in Iraq. - Arch. Polish Fish. 4 (1): 113-124.

[8] Bilici, S. (2013): The investigations on the biology of Carasobarbus luteus, Capoeta trutta and Garra variabilis species Living in Tigris River. $\mathrm{PhD}$ thesis - Institute of Natural And Applied Sciences University of Dicle.

[9] Bilici, S., Ünlü, E., Çiçek, T., Satici, Ö. (2016): The reproductive biology of Carasobarbus luteus and Capoeta trutta in the Tigris River, Turkey. - Cybium 40 (2): 147-153.

[10] Bilici, S., Cicek, T., Ünlü, E. (2017): Observation on the age, growth and somatic condition of Carasobarbus luteus (Heckel, 1843) and Capoeta trutta (Heckel, 1843) (Cyprinidae) in the Tigris River, Turkey. - Iranian Journal of Fisheries Sciences 16 (1):170-187.

[11] Borkenhagen, K., Esmaeili, H. R., Mohsenzadeh, S., Shahryari, F., Gholamifard, G. (2011): The molecular systematics of the Carasobarbus species from Iran and adjacent areas, with comments on Carasobarbus albus (Heckel, 1843). - Environ. Biol. Fish. 91: 327-335.

[12] Britannica. (2018): Tigris-Euphrates river system. Britannica. Accessed February 08. https://www.britannica.com/place/Tigris-Euphrates-river-system

[13] Cardenas, L., Silva, A., Magoulas, A., Cabezas, J., Poulin, E., Ojeda, F. (2009): Genetic population structure in the Chilean jack mackerel, Trachurus murphyi (Nichols) across the Southeastern Pacific Ocean. - Fish Res. 100:109-115.

[14] Coad, B. W. (2010): Freshwater Fishes of Iraq. - Sofia-Moscow. Pensoft Publishers, 294 $\mathrm{pp}$.

[15] Çelik, B., Saler, S. (2016): Atatürk Baraj Gölü'nde Yaşayan Bizir, Carasobarbus luteus (Heckel, 1843)'un Sindirim Sistemi İçeriği. - Journal of Limnology and Freshwater Fisheries Research 2 (2): 83-93.

[16] Darabi, A. R., Kashan, N., Fayazi, J., Aminafshar, M., Chamani, M. (2014): Investigation of phylogenetic relationship among two Barbus species (Cyprinidae) populations with mitochondrial DNA using PCR sequencing. - IJBPAS, 4 (2): 302-311.

[17] Eydizadeh, A. (2014): Some biological aspect of Carasobarbus luteus in Hoor Al-azim wetland. - Sci. J. Biol. Sci. 3 (3):29-36.

[18] Fennando, P., Pfrender, M. E., Encalada, S. E., Lande, R. (2000): Mitochondrial DNA variation, phylogeography and population structure of the Asian elephant. - Heredity $84: 362-72$.

[19] Filipova, L., Lieb, D. A., Grandjean, F., Petrusek, A. (2011): Haplotype variation in the spiny-cheek crayfish Orconectes limosus: colonization of Europe and genetic diversity of native stocks. - J. N. Am. Benthol. Soc. 30: 871-881. 
[20] Gruenthal, K. M., Acheson, L. K., Burton, R. S. (2007): Genetic structure of natural populations of California red abalone (Haliotis rufescens) using multiple genetic markers. - Mar Biol. 152:1237-1248.

[21] Gökçek, K. Akyurt, I. (2008): Age and Growth Characteristics of Himri Barbel (Barbus luteus Heckel, 1843 in Orontes River, Turkey. - Turk J. Zool. 32: 461-467.

[22] Hall, T. A. (2013): BioEdit v 7.2.3. - Biological sequence alignment editor for Win 95/98/NT/2K/XP7.

[23] Hu, J., Zhang, J., Nardi, F., Zhang, R. J. (2008): Population genetic structure of the melon fly, Bactrocera cucurbitae (Diptera: Tephritidae), from China and Southeast Asia. Genetica 134: 319-324.

[24] Hu, Y. D., Pang, H. Z., Li, D. S., Ling, S. S., Lan, D., Wanga, Y., Zhu, Y., Li, D. Y., Rong-Ping, W., Zhang, H. M., Wang, C. D. (2016): Analysis of the cytochrome c oxidase subunit 1 (COX1) gene reveals the unique evolution of the giant panda. - Gene 592: 303307.

[25] Kuru, M. (1979): The fresh water fish of South-eastern Turkey-2 (Euphrates-Tigris sisteme). - Hacettepe Bull. Nat. Sci. Eng. 7-8: 105-114.

[26] Li, W., Chen, X., Xu, Q., Zhu, J., Dai, X., Xu, L. (2015): Genetic Population Structure of Thunnus albacares in the Central Pacific Ocean Based on mtDNA COI Gene Sequences. - Biochem. Genet. 53: 8-22. http://dx.doi.org./10.1007/s10528-015-9666-0.

[27] Liu, G., Zhou, L. (2016): Population genetic structure and molecular diversity of the red swamp crayfish in China based on mtDNA COI gene sequences, - Mitochondrial DNA Part A, http://dx.doi.org./10.1080/24701394.2016.1199022.

[28] Ma, C., Cheng, Q., Zhang, Q., Zhuang, P., Zhao, Y. (2010): Genetic variation of Coilia ectenes (Clupeiformes: Engraulidae) revealed by the complete cytochrome $\mathrm{b}$ sequences of mitochondrial DNA. - J. Exp. Mar. Bio. Ecol. 385:14-19.

[29] Naama, A. K., Muhsen, K. A. (1986): Feeding periodicities of the mugilid Liza abu (Heckel) and cyprinid Carasobarbus luteus (Heckel) from Al-Hammar Marsh, southern Iraq. - Indian J. Fish. 33: 347-350.

[30] Near, T. J., Pesavento, J., Cheng, C. (2003): Mitochondrial DNA, morphology, and phylogenetic relationships of Antarctic icefishes (Notothenioidei: Channichthyidae). Mol. Phylogenet. Evol. 28: 87-98.

[31] Nei, M., Li, W. (1979): Mathematical model for studying genetic variation in terms of restriction endonucleases. - Proc. Nat. Acad. Sci. 76: 5269-73.

[32] Nei, M. (1987): Molecular evolutionary genetics. - New York, Columbia University Press., 512 pp.

[33] Ortega-Villaizan Romo, M., Suzuki, S., Nakajima, M., Taniguchi, N. (2006): Genetic evolution of inter individual relatedness for broodstock management of the rare species barfin flounder Verasper moseri using microsatellite DNA markers. - Fisheries Sci. 72: 33-39.

[34] Parmaksız, A., Ekşi, E. (2017): Genetic diversity of the cyprinid fish Capoeta trutta (Heckel, 1843) populations from Euphrates and Tigris rivers in Turkey based on mtDNA COI sequences. - Indian J. Fish. 64 (1): 18-22. http://dx.doi.org/ 10.21077/ijf.2017.64.1.62396-03.

[35] Rahemo, Z. I., Al-Shatter, N. M. (2012): Observations on reproductive organs and tissues of two freshwater Cyprinid fishes. - Trends Fish. Res. 1 (2): 42-48.

[36] Rohl, A. (1999): NETWORK: A program package for calculating phylogenetic network. Version 2.0b. Available from: http://www.fluxus-engineering.com.

[37] Rozas, J., Sanchez-DelBarrio, J. C., Messeguer, X., Rozas, R. (2003): DnaSP DNA polymorphism analyses by the coalescent and other methods. - Bioinformatics. 19: 24962497.

[38] Saraswat, D., Lakra, W. S., Nautiyal, P., Goswami, M., Shyamakant, K., Malakar, A. (2014): Genetic characterization of Clupisoma garua (Hamilton 1822) from six Indian 
populations using mtDNA cytochrome b gene. - Mitochondrial DNA, 25 (1): 70-77. http://dx.doi.org/10.3109/19401736.2013.782014

[39] Ünlü, E. (1991): A study on the biological characteristics of Capoeta trutta (Heckel, 1843) living in the Tigris River, Turkey. - Turk. J. Zool. 15: 22-38.

[40] Ward, R. D. (2000): Genetics in fisheries management. - Hydrobiologia 420:191-201.

[41] Xu, Z. H., Chen, J. L., Cheng, D. F., Liu, Y., Eric, F. (2011): Genetic variation among the geographic population of the Grain Aphid, Sitobion avenae (Hemiptera: Aphididae) in China inferred from mitochondrial COI gene sequence. - Agr. Sci. China. 10: 1041-1048.

[42] Zeybek, M., Ahiska, S., Y1ldı, S. (2016): A preliminary taxonomical investigation on the Oligochaeta (Annelida) fauna of Tigris River (Turkey). - Ege Journal of Fisheries and Aquatic Sciences 33 (1): 47-53. http://dx.doi.org/ 10.12714/egejfas.2016.33.1.08. 